\title{
Analyzing the Efficiency of Human Capital in Clusters through Continuing Vocational Training
}

\author{
Alina Natalia POP ${ }^{\star}$
}

\begin{abstract}
A B S T R A C T
This paper aims at bringing to the fore the role of clusters in the North-West development region of Romania, having as main actors the human resource, identifying the opportunities of industrial organizations, the degree of improvement and geographical distribution, contributing to the integration of a continuous training system as a means of development clusters with new solutions and organizations at a highly successful regional level. Data on the economic success of a region focuses on the specialization of supply, the development of key areas, providing competitive advantages, skills and qualified resources that have been gained over the past years of research. This study highlights the ability to develop a strategy for human resource development. Such research is extremely useful as it complements other previous studies on this complexity, know-how transfer, technology transfer, and knowledge management, capital investment, cluster relationships, performance, key factors in capital development human.
\end{abstract}

(c) 2019 EAI. All rights reserved.

\section{Introduction}

At Northwest Development Region level we can state that it is a major pole of investors in various fields, with a significant growth in cluster development in IT, furniture, agro, spa, renewable energy, offering services and products adapted to new challenges and standards of the European and national legislative framework in order to increase the pace of market integration.

We can say that Romania is on second place in the Eastern European IT market with a skilled workforce, receptive to Western organizational and cultural values. By implementing various projects that lead to prosperity, cohesion, international, national and regional competitiveness, becoming economic and social politicians able to manage organizations to make spatial relations more efficient and territorial integration, a significant educational breakthrough in human resources and technological process.

Performance is very important at organizational level, but also in human resources. Every employee tries to be performing at work, leading to efficiency, effectiveness and competitiveness in the organization. Within an organization, performance requires access to well-qualified resources that lead to optimizing the productive process through high standards, competitiveness, motivation through appropriate remuneration, workplace satisfaction and organizational development.

Practical value also stems from cluster utilization of the innovative human resource capability through the implementation of new technologies and adaptation to new European standards. In recent analyzes, the attribution of human capital is to intensify economic activity through specialization and the formation of specialized clusters as a necessary stage in the economic evolution of society. Investing in human capital gains new valences, human capital theory focusing on the economic efficiency of investment in education.

Human capital as a result of investing in individual capacities and qualities leads to increased labor productivity and income. These capacities and qualities of the individual contributed to to the birth and progress of new technologies, providing new economic fundamentals, based on the innovative ideas that give rise to the innovation economy. Investing in human capital means getting benefits for individuals, companies and society.

The allocation by clusters of allowances in human resource progress leads to a necessary advantage for economic progress, prioritizing the human resource as an important element of the cluster development within the researched region. 


\section{Literature review}

Michael Porter was the one who contributed to substantiate the factors of production of classical theory through of the diamond of competitiveness, from which the concept of clusters resulted.

The three large-scale systems in cluster organizations are: the centralized French one, the German one combining adaptable sketches at regional and national level, being the most complex and the Swedish, implementing the triple helix model of research institutes, industries, universities and local and regional public authorities.

In Romania, experience has shown that the three partners of the "Triple helix" model do not cooperate, more than they do not know and do not talk to each other. It turned into a four clover model, the fourth actor being represented by catalyst organizations - consultancy firms profiled on the exchange of technologies and innovations. (Cosnita, D., Guth, M ., 2010).

These long-term clusters need to be delivered through sustainable innovations, attracting resources, companies, new skills, venture capital, boosting global attractiveness and access to a dynamic market.

Clusters are highlighted as regional clusters but are nationally and internationally involved in organizations specialized in multiplying the clustering phenomenon and attracting as many organizations and catalysts as possible with a skilled human resource specialized in various fields and leading to improving the process of integration, innovation and organizational efficiency.

Clusters developed at the regional level as innovative are a superior stage, ensuring economic growth at regional level (J. Weller, 2001) by promoting innovation (Engel J., S., del Palacio I., 2009).

Based on the statistical analyzes, cluster objectives can be grouped as follows:

a. Research and networking

Many cluster-building initiatives include information, exchange of information at seminars, inviting specialists, creating web pages (Lee, 2009). For example, the Vlaams software platforms (Flanders, Belgium) set up in 1999 constituted a cluster-building initiative and aimed at organizing seminars, short courses, and transfer of new information between companies and organizations. Networking is also central to most cluster-building initiatives. (A. Tănțău, 2011)

\section{b. Political action}

Lobbying and creating communication support between industrial organizations, authorities involved, and the scientific environment is another important set of objectives.

\section{c. Commercial cooperation}

Commercial cooperation includes a number of objectives, joint procurement, business assistance, marketing consulting, and export promotion (Waluszewski A., 2004).

\section{d. Coeducation and training}

These include training of managers and training of employees.

\section{e. Innovation and technology}

Cluster initiatives can facilitate streamline process renewal and technology change (Scheel, 2002). Thus new standards can be presented of new knowledge technologies and for improving the production process. (A. Tănţău, 2011)

\section{f. Expansion of the cluster}

Many cluster-building initiatives aim to develop a particular region by promoting a brand and foreign direct investment in the region.

Figure 1 presents the benefits of training, specialization, innovation in clusters:

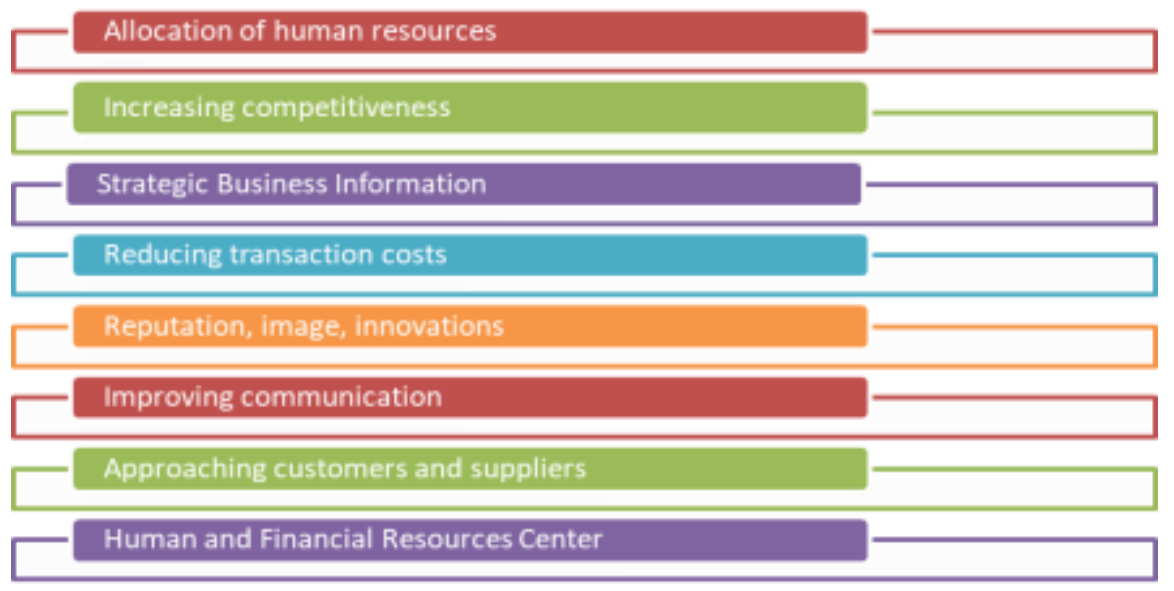

Fig. 1. Advantages of clusters

Source: own processing 
The innovative cluster is a strategy to promote innovative business dimensions to optimize competitiveness and integrate into the international market. (Chang Y., C, et al., 2008). (A. Tănţău, 2011). These include:

- the need to reduce technical and economic uncertainty;

the need for permanent interaction between organizations and catalysts;

… the need for immediate relationships between organizations training and knowledge transfer (Giuliani, Bell, 2005).

Formation of clusters requires a significant effort to drive competitiveness at the level of the analyzed region through the involvement of organizations, authorities, technology schools, universities, research institutes.

Clusters offer the opportunity to multiply productivity, due to accessibility to specialized workforce, suppliers, new information resources and a continuous business development program. The cluster allows the promotion of innovations by increasing people's ability to identify opportunities for new products or new processes. Clusters also facilitate the marketing of innovations by creating new enterprises of regional interest. (A. Tănţău, 2011)

Collaboration between cluster members provides an identity on the national and European market, organizational support, new status, better dissemination of information, better cost efficiency and fund management.

An important asset is their proximity, the trust of each organization in their own activities, efficient communication and strategic information exchange that lead to optimal decisions in organizing the organization, improving the quality of competitive strategies and streamlining management to the new requirements of the international market. (A. Tănţău, 2011)

Regional cluster development conferences lead to a new trend in areas such as IT, renewable energies, research, etc. open to new employment opportunities, teamwork. There is specialized workforce within the cluster, and operational costs with recruitment, selection and employment are diminished as cluster organizations identify specialized human resources. Relationships between suppliers, customers and other catalysts lead to lower spending regional site, the proximity between them and the individualisation of the services offered according to their requirements and adapted to the technological progress, and the capitalization of the local resources diminishes the travel costs for the conclusion of partnerships, contracts in order to carry out the productive process.

The investment made by organizations periodically to facilitate a resource-based specialization, develops various collaborations, allows for positive thinking, implementation of new development strategies, contributing to harmonious regional development, attracting new investors and new outlets.

\section{Analysis of clusters from the perspective of investment in human capital at the level of the North- West region of Romania}

Competitiveness of clusters can be analyzed from the perspective of two indicators:

\section{Quantitative analysis}

In the quantitative analysis, the following analysis indicators were considered:

둘 Importance - the turnover of the pole, the gross domestic product;

둘 Size - identifies the number of employees per domain;

둘 Specialization - identifies the number of cluster employees;

- Concentration - identifies the number of employees per cluster;

둘 Export - tracking the value of exports by sector;

둘 Innovation - includes sub-sectors, dimensions of innovation (human resources, R \& D system, support and funding, investment, cooperation and entrepreneurship as well as outputs of product innovation, process, economic effects.

\section{Qualitative analysis}

In the qualitative analysis, the following analysis indicators were considered:

․ㅜㄹ Geographic Concentration - Investigates the concentration of industrial branches in a particular regional area;

둘 $\mathrm{R} \& \mathrm{D}$ - investigates the existence of universities, research institutes in the respective geographic agglomeration.

둘 Labor Force - investigates its availability (quantity), the quality and existence of centers for improvement the level of economic agglomeration.

- Cooperation - investigates the existence of partnership relations between the members of the industrial agglomeration concerned. It is a critical factor that differentiates a cluster from a well positioned regional competitor.

- Catalyst institutions - investigates the existence of clustering process mediators (technology transfer centers, chambers of commerce, consultants, etc.). 
둘 Internationalization: Investigates the orientation towards the international markets of that cluster.

In the analysis, statistical data sources were used: the Romanian Statistical Yearbook, the Innovation Trendchart Report, other statistical data at regional level, as well as those obtained from clusters studied in the North-West region following the application of the questionnaire.

The cluster is, by and large, a qualitative approach, having to cope with the desire of some actors to harmonize their interests within a common strategy and objectives. At regional level, the quantitative analysis follows logically from the qualitative one, because it is necessary to analyze existing competitiveness poles. At national level, quantitative analysis validates qualitative products.

Figure 2 shows the clusters of existent clusters within the Northwest region:

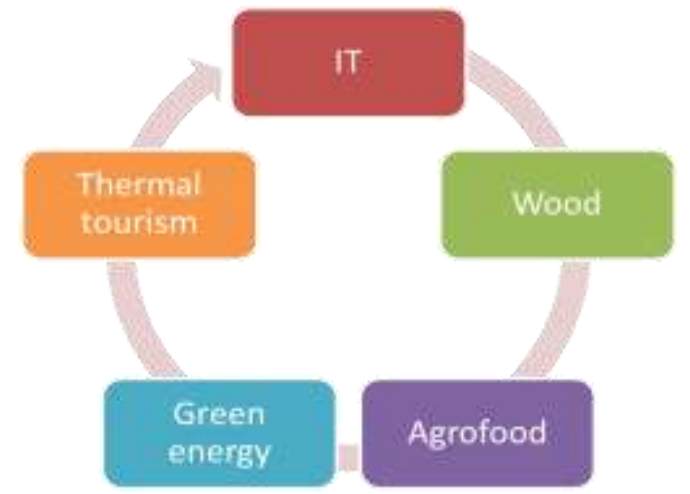

Fig. 2.. Predominant clusters in the region Source: own processing

Each company can have its own options in terms of how to invest in its human resources, in order to develop it professionally under the conditions defined by the legislative framework. A factor with a major influence in adopting the organization's rules in the field of training is its investment capacity, in direct relation to the number of employees, the type of capital invested, the field of activity, the human resources management, the availability and motivation of the staff to develop. In order to identify the position of the companies in supporting employees for professional development, it is necessary an analysis of the need for continuous training of employees is required.

The overall objective of the research focuses on identifying cluster relationships and the specialized human resource in the researched region in order to influence competitiveness.

Thus, the qualitative and quantitative data extracted from the application of the target group questionnaire will be analyzed with the statistical data analysis programs SPSS 20 and EXCEL 2010, thus generating statistical and mathematical testing to conclude support for hypotheses applied on the NorthWest development region of Romania.

Questions made to formulate research hypotheses are:

1. What are the means of integrating clusters into a prosperous economic system?

2. What is the current state of human resource training in industrial organizations?

3. What is the link between human capital output and cluster development?

Based on these questions, the following assumptions were made:

1. Does allocation of financial resources have an effect on human capital?

2. Does specialized human capital lead to cluster development?

3. Can relationships in clusters lead to performance?

Following the application of the questionnaire in the 100 organizations, within the clusters on granting investments for performance, development and multiplication through the hypothesis. Organizations have been open to completing the questionnaire, providing relevant information for this research, but of course, there have also been detentions from organizations or even refusal to participate in this research.

Data analysis is performed with the SPSS 20.00 program that offers the possibility of determining correlations, graphical interfaces, offering the possibility of advanced quantitative and qualitative research. We can predict, plan, develop new models for the organization related to human resource training, investment in training, cluster development and efficiency.

It is confirmed that the 100 respondents are valid after the analysis and, after testing the internal consistency, results in a Croncbach Alpha coefficient with the value of .917, which leads to the idea that it is valid and will yield conclusive results. 
Table no. 1. The Croncbach Alpha value for the 30 questions and for the two sub-topics of the proposed questionnaire

\begin{tabular}{ll} 
Reliability Statistics & \\
\hline Cronbach's Alpha & N of Items \\
\hline .973 & 30 \\
\hline .917 & 3
\end{tabular}

source: (data analyzed for the SPSS 20.00 statistical program) follows:

This analysis is performed using the ANOVA method, which results in data from table no. 2, as

Table no. 2. Table ANOVA

\begin{tabular}{|c|c|c|c|c|c|c|}
\hline \multicolumn{7}{|l|}{ ANOVA Table } \\
\hline & & $\begin{array}{l}\text { Sum of } \\
\text { Squares }\end{array}$ & df & $\begin{array}{l}\text { Mean } \\
\text { Square }\end{array}$ & $\mathrm{F}$ & Sig. \\
\hline \multirow{3}{*}{$\begin{array}{l}\text { Performance } \\
\text { Investing in human } \\
\text { capital }\end{array}$} & $\begin{array}{l}\text { Between } \\
\text { Groups }\end{array}$ & 21,056 & 49 & 430 & $\begin{array}{l}11,00 \\
7\end{array}$ &, 000 \\
\hline & Within Groups & 1,952 & 50 & 039 & & \\
\hline & Total & 23,008 & 99 & & & \\
\hline
\end{tabular}

Given that the value of $F$ is 11,007 and the significance level, Sig $=0,000$, we can conclude that the null hypothesis is rejected and that the two predictor variables (investment in human capital, relations in the cluster framework,) influences performance.

Table no. 3. Association Table

\begin{tabular}{|l|l|l|}
\hline Measures of Association & Eta & Eta Squared \\
$\begin{array}{l}\text { Performance } \\
\text { Investing in human capital }\end{array}$ &, 957 &, 915 \\
\hline
\end{tabular}

source: (data analyzed for the SPSS 20.00 statistical program)

We can say that there is a positive correlation between performance and investment, being .957, influencing organizational development.

Table no. 4. Table ANOVA

\begin{tabular}{|c|c|c|c|c|c|c|c|c|}
\hline \multicolumn{9}{|l|}{ ANOVA Table } \\
\hline \multirow{5}{*}{$\begin{array}{l}\text { PERFORMANCE } \\
\text { RELATIONSHIP } \\
\text { BETWEEN } \\
\text { CLUSTERS }\end{array}$} & \multirow{5}{*}{ * } & & \multirow{3}{*}{$\begin{array}{l}\text { (Combin } \\
\text { ed) }\end{array}$} & $\begin{array}{l}\text { Sum of } \\
\text { Squares }\end{array}$ & $\mathrm{df}$ & \multirow{3}{*}{$\begin{array}{l}\text { Mean } \\
\text { Square } \\
, 399\end{array}$} & \multirow{3}{*}{$\begin{array}{l}F \\
7,203\end{array}$} & \multirow{3}{*}{$\begin{array}{l}\text { Sig. } \\
, 000\end{array}$} \\
\hline & & Between & & 20,349 & 51 & & & \\
\hline & & Groups & & & & & & \\
\hline & & Within Groups & & 2,659 & 48 & ,055 & & \\
\hline & & Total & & 23,008 & 99 & & & \\
\hline
\end{tabular}

source: (data analyzed for the SPSS 20.00 statistical program)

Given that the value of $F$ is 7,203 and the significance level, Sig $=0,000$, we can conclude that the hypothesis is rejected and that the two variables influence the variable (performance).

Tabelul nr. 5. Tabelul de asociere

\begin{tabular}{llll}
\hline Measures of Association & & \\
& Eta & Eta Squared \\
PERFORMANCE & $*$ &, 940 &, 884 \\
RELATIONSHIP & & \\
BETWEEN CLUSTERS & \\
source: (data analyzed for the SPSS 20.00 statistical program)
\end{tabular}

In the second situation, the relation between performance and clustering relationships is positive, with a value of 940 , and can be said to validate the correlation between them.

After analyzing the two relationships, it can be seen that the strongest link is investmentperformance, which leads to an interest from organizations for staff qualification, organization of trainings, 
participation in various workshops, conferences that bring in the first place, the novelties in each area under consideration and organizational set-up to provide a prosperous, associative and innovative framework.

We can conclude that through the multiple regression analysis, the correlation relations between the RSC variables (labor, community, market, environment) and the competitiveness of the firm.

Linear connection allowed the criterion variable and predictors $(F=1370.358, p<.001)$ was identified with a multiple correlation coefficient $\mathrm{R}=.981$.

Approximately $97 \%$ of the variance of the company's competitiveness can be explained by the simultaneous contribution of the four variables, which is why there is a significant connection between existence of activities (community, labor, market, environment) and increased competitiveness within the industrial organizations the chosen development region;

All these findings can also be graphically represented, the SPSS 20.00 statistical program, providing a multitude of graphical interpretations based on those statistically found.

\section{Conclusions}

In the activity of exploration the factors for increasing the efficiency of human capital, using models based on econometric methods, it is assumed that the investment in human capital will continue to have an increasing trend over a foreseeable period, with the involvement of organizations, cluster members and correlated with the national and European legislative framework in force. In order to be relevant in establishing the organization's development strategy, the analysis of knowledge management implementation under analysis should be compared to market dynamics, activity and results. If the place of sale is more dynamic than the company, it will be noticed that the company will have a certain gap in terms of competition.

The importance of statistical means and models applied to the market circuit, together with the increasing complexity of the organization's economic and financial activity, with profound implications in the management process, can not only be experienced and routine, , further requiring relevant studies and analyzes to underpin operative and strategic decisions.

We can conclude that, by further analysis of standardized residual data and transformed values, there is a positive influence that reinforces this important conclusion between organizational activities (investment in human capital, cluster relations, performance) and increased competitiveness within industrial organizations in the chosen development region.

\section{References}

1. Ajitabh J, Momaya Kirankumar, (2004), Competitiveness of Firms: Review of theory, frameworks and models. Singapore Management Review.

2. Andrei, T, Bourbonnais, R. (2008). Econometrie, Editura Economică, Bucuresti.

3. Brătianu C-tin. ZbucheaA. (2016).Opportunities and Risks in the Contemporary Business Environment, Bucuresti

4. Cosnita D., Guth M., (2010), Clusters and Potential Clusters in Romania - A Mapping Exercise.

5. Dan M. (2012), Innovative clusters: a solution for the economic development of Romania, Theoretical and Applied Economics Volume XIX (2012), No. 9(574), pp. 5-16.

6. Engel J., S., del Palacio I. (2009) Global networks of clusters of innovation: Accelerating the innovation process, Business Horizons, 52, 493-503;

7. Guth, M. and Cosnita, D. (2010), Clusters and potential clusters in Romania, GTZ Report

8. Jürgen Weller. (2001) Economic reforms, growth and employment: labour markets in Latin America and the Caribbean, United Nations Publication Santiago, Chile

9. Levente, Szász, (2011), Contribuţii privind perfecţionarea strategiei operaţionale a înteprinderii industriale. Cluj Napoca: Universitatea „BABEŞ-BOLYAI” Cluj Napoca.

10. Lee C.,Y. (2009) Do firm in cluster invest in R\&D more intensively? Theory and evidence from multicountry data, Research Policy, 38, 1159-1171;

11. Manole Al., Diaconu A., Anghel M. G., (2014) , General aspects concerning the development of the North-West Region of Romania. http://www.revistade statistica.ro/supliment/wp-content/uploads/2014/11/RRSS19_2014_A11.pdf

12. M. Popa - APIO (2015) Metodologia cercetării (note de curs), Modelul cercetării empirice.

13. M. Argăseală, M. Bălan, M. Balica, C. Bîrzea, A. Ciobanu, C. Fartușnic, C. Gheorghe, I. Horga, M. Jigău, G. Jurcan, C. Măruță, N. Plugărescu, A. Sîmpetru, F. Tacea, C. Ulrich, L. Voicu, (2012), "Formarea continuă a angajaților - șansa unor întreprinderi inovative cu angajați pasionați de munca lor", POSDRU/62/2.3/S/22025, București, http://www.invatapentrutine.ro/library/files/brosura_strategie_nationala_invata_pentru_tine!.pdf

14. Popescu, C. (2010), Industrial Clusters and Regional Development in Romania, Human Geographies - Journal of Studies and Research in Human Geography 4.2, page 17-34.

15. Porter, M. (1998), "Clusters and the new economics of competition”, Harvard Business Review, reprint 98609, Nov-Dec 1998, pp.77-90, http://hdrnet.org/349/1/porter.studie.pdf, Project Management Institute (2008), A guide to the project management body of knowledge (PMBoK Guide), 3rd edition, Project Management Institute, Newtown Square;

16. Valentin Cojanu, Dragos Pîslaru (2011) "How important are agglomeration economies: a case study of Romanian industrial clusters" Review of Economic and Business Studies 4:1, pp. 35-58.

17. ${ }^{* * *}$ Cluster Management Guide - Guidelines for the Development and Management of Cluster Initiatives, Cloe project www.clusterforum.org

18. *** Ghid de bună practică pentru clustere și rețele de firme, A. Tănțău, (2011), Editura Print Group, București.

19. ***http://epp.eurostat.ec.europa.eu/portal/page/portal/education/data/database

20. *** http://www.clusterobservatory.eu. 